\title{
PENGARUH MODEL PEMBELAJARAN KOOPERATIF TIPE NUMBERED HEAD TOGETHER(NHT) TERHADAP HASIL BELAJAR SISWA PADA MATERI USAHA DAN ENERGI
}

\author{
Fitri Melia Harahap dan Henok Siagian \\ Jurusan Fisika FMIPA Universitas Negeri Medan \\ Jalan Willem Iskandar Pasar V Medan, 20221
}

\begin{abstract}
ABSTRAK
Penelitian ini bertujuan untuk mengetahui pengaruh model pembelajaran Kooperatif Tipe Numbered Head Together (NHT) terhadap hasil belajar siswa pada materi usaha dan energi di kelas XI semester I SMA Negeri 1 Percut Sei Tuan T.P 2013/2014. Jenis penelitian ini adalah quasi experiment. Populasi dalam penelitian ini adalalah seluruh siswa kelas XI yang terdiri dari 4 kelas yang berjumlah 163 siswa. Sampel penelitian diambil dengan cara cluster random sampling, yaitu Kelas $\mathrm{XI}^{-}{ }_{3}$ berjumlah 40 siswa diajar dengan menggunakan model pembelajaran kooperatif tipe $\mathrm{NHT}_{\text {dan }}$ kelas $\mathrm{XI}^{-}$ berjumlah 40 siswa diajar dengan menggunakan model pembelajaran konvensional. Instrumen yang digunakan dalam penelitian ini adalah tes hasil belajar dalam bentuk pilihan berganda sebanyak 15 soal yang telah memenuhi validitas isi. Hasil penelitian pretes diperoleh kedua kelas berdistribusi normal dan homogen. Berdasarkan data pretes dengan menggunakan uji t diperoleh bahwa kemampuan awal siswa pada kelas eksperimen dengan kelas kontrol adalah sama. Setelah selesai pembelajaran, dilakukan postes dengan hasil nilai rata-rata postes kelas eksperimen 73,67 dan kelas kontrol sebesar 66,67. Data kedua kelas menunjukkan berdistribusi normal dan homogen. Berdasarkan hasil uji hipotesis dengan menggunakan uji t pada taraf nyata $\alpha=0,05$ diperoleh bahwa ada perbedaan hasil belajar antara penerapan model pembelajaran kooperatif tipe NHT dengan pembelajaran konvensional, dengan kata lain model kooperatif tipe NHT memberikan pengaruh yang signifikan dalam meningkatkan hasil belajar siswa pada materi Usaha dan Energi di Kelas XI Semester I SMA Negeri 1 Percut Sei Tuan T.P $2013 / 2014$.
\end{abstract}

Kata Kunci : Model Pembelajaran Kooperatif Tipe Numbered Head Together (NHT), Hasil Belajar Siswa.

\section{PENDAHULUAN}

Pendidikan merupakan bagian integral dalam pembangunan. Proses pendidikan tidak dapat dipisahkan dari proses pembangunan itu sendiri. Pendidikan memegang peranan penting dalam mempersiapkan sumber daya manusia yang berkualitas. Pendidikan merupakan salah satu kebutuhan pokok manusia. Pendidikan tidak diperoleh begitu saja dalam waktu yang singkat, namun memerlukan suatu proses pembelajaran sehingga 
menimbulkan hasil atau efek yang sesuai dengan proses yang dilalui, oleh karena itu pendidikan hendaknya dikelolah baik secara kualitas maupun kuantitas. Pendidikan merupakan peran yang sangat strategis dalam rangka menghasilkan SDM Indonesia seutuhnya baik sebagai individu maupun sebagai anggota masyarakat. "Berdasarkan Undangundang Sistem Pendidikan Nasional No.20 tahun 2003 Bab I, bahwa pendidikan adalah usaha sadar dan terencana untuk mewujudkan suasana belajar dan proses pembelajaran agar peserta didik secara aktif mengembangkan potensi dirinya untuk memiliki kekuatan spiritual keagamaan, pengendalian diri, kepribadian, kecerdasan, akhlak mulia, serta keterampilan yang diperlukan dirinya, masyarakat, bangsa dan negara (Sudrajat, 2008)".

Pemerintah dalam hal ini berupaya meningkatkan mutu pendidikan dengan pengembangan atau penyempurnaan kurikulum, melengkapi sarana dan prasarana pendidikan, pengembangan sistem penilaian hasil belajar dan sebagainya. Sekolah merupakan lembaga formal yang menyelenggarakan dan melaksanakan serangkaian kegiatan belajar terencana, terarah dan terpadu. Sekolah merupakan tempat berlangsungnya kegiatan belajarmengajar. Proses pembelajaran di sekolah adalah interaksi guru dengan siswa, untuk mempelajari materi yang telah tersusun dalam suatu kurikulum. Salah satu materi pelajaran yang dipelajari di sekolah adalah fisika.

Fisika merupakan salah satu cabang IPA, yang menekankan peserta didik dapat memperoleh pengalaman langsung, sehingga dapat menambah kekuatan untuk menerima, menyimpan, dan menerapkan konsep yang dipelajarinya. Dengan demikian, peserta didik terlatih untuk dapat menemukan sendiri berbagai konsep yang dipelajarinya secara menyeluruh (holistik), bermakna, autentik, dan aktif, karena dalam belajar fisika seseorang dituntut untuk berpikir berdasarkan pengalaman dan menerapkan konsep-konsep dalam kehidupan sehari- hari.

Berdasarkan hasil observasi yang dilakukan peneliti di SMA Negeri 1 Percut Sei Tuan melalui wawancara dengan guru bidang studi fisika diperoleh bahwa guru cenderung masih menggunakan model pembelajaran konvensional dengan metode ceramah, tanya jawab dan penugasan. Selain itu, nilai fisika yang diperoleh siswa belum mencapai standar Kriteria Ketuntasan Minimum (KKM) yang berkisar antara 55-65. Hal ini disebabkan siswa tidak menyukai fisika karena sulit dipahami dan kurang menarik.

Berdasarkan hasil wawancara dengan guru Fisika tersebut, peneliti juga memberikan angket persepsi siswa terhadap pelajaran Fisika kepada 40 siswa kelas XI. Dari hasil angket tersebut diperoleh kesimpulan bahwa siswa kurang berminat terhadap pelajaran fisika dan kurang aktif bertanya dan mengemukakan pendapatnya dalam proses pembelajaran, juga tidak berusaha mempelajari fisika diluar sekolah seperti bimbingan atau private sehingga mengalami kesulitan dalam belajar fisika.

Berdasarkan uraian di atas,
maka menurut peneliti perlu


diterapkan suatu sistem pembelajaran yang melibatkan peran siswa secara aktif dalam kegiatan belajar mengajar, guna meningkatkan hasil belajar fisika. Salah satunya adalah model pembelajaran kooperatif. Melalui model pembelajaran ini siswa dapat mengemukakan pemikirannya, saling bertukar pendapat, saling bekerja sama, saling membantu jika ada yang mengalami kesulitan, serta berusaha mengkaji dan menguasai mata pelajaran fisika sehingga dapat meningkatkan hasil belajar fisika.

$$
\text { Pembelajaran kooperatif }
$$
adalah salah satu bentuk pembelajaran berdasarkan paham konstruktivis dan merupakan strategi belajar dengan jumlah siswa sebagai anggota kelompok kecil yang tingkat kemampuannya berbeda. Dalam penyelesaian tugas kelompok harus saling bekerja sama dan saling membantu untuk memahami materi pelajaran (Isjoni, 2009:14).

Model pembelajaran kooperatif yang dipilih dalam penelitian ini adalah Model pembelajaran kooperatif tipe Numbered Head Together (NHT). Model pembelajaran kooperatif tipe NHT ini menuntut siswa untuk lebih bertanggung jawab terhadap tugas yang diberikan karena setiap siswa dalam suatu kelompok tersebut akan diberi nomor yang berbeda.

Teknik ini memberi kesempatan kepada siswa untuk saling membagikan ide - ide dan mempertimbangkan jawaban yang paling tepat dan meningkatkan semangat kerja sama mereka (Lie, 2008:59). Sehingga akan memudahkan siswa untuk memahami materi yang dipelajari dan memudahkan untuk berinteraksi serta berkomunikasi dengan satu sama lain.

Adapun Langkah-langkah model pembelajaran kooperatif tipe NHT yang dikembangkan oleh Arends (2008: 16).

\section{Langkah 1. Numbering}

Guru membagi siswa menjadi beberapa tim beranggotakan tiga sampai lima orang dan memberi nomor sehingga setiap siswa pada masing-masing tim memiliki nomor antara 1 sampai 6.

Langkah 2. Questioning

Guru mengajukan sebuah pertanyaan - pertanyaan kepada siswa. Pertanyaannya bisa bervariasi.

Langkah 3. Heads Together

Siswa "menyatukan kepalanya" berfikir bersama untuk menemukan jawabannya dan memastikan bahwa semua orang tahu jawabannya

Langkah 4. Answering

Guru memanggil sebuah nomor dan siswa dari masing-masig kelompok yang memiliki nomor itu mengangkat tangannya dan memberikan jawabannya kehadapan seluruh kelas.

Tujuan penelitian ini adalah untuk : (1) Mengetahui hasil belajar siswa yang diajar dengan model pembelajaran kooperatif tipe NHT pada materi Usaha dan Energi. (2) Mengetahui hasil belajar siswa yang diajar dengan model Pembelajaran Konvensional pada materi Usaha dan Energi. (3) Mengetahui pengaruh penggunaan model pembelajaran kooperatif tipe NHT terhadap hasil belajar siswa pada materi Usaha dan Energi. 


\section{METODE PENELITIAN}

Penelitian ini dilaksanakan di SMA Negeri 1 Percut Sei Tuan dengan populasi seluruh siswa kelas XI sebanyak 4 kelas terdiri dari 163 siswa. Sampel dipilih 2 kelas secara acak (Cluster Random Sampling) yaitu, kelas XI-3 (40 siswa) dijadikan kelas eksperimen yang diajar dengan menggunakan model pembelajaran kooperatif tipe NHT dan kelas XI-4 (40 siswa) dijadikan sebagai kelas kontrol yang diajar dengan menggunakan model pembelajaran Konvensional.

Adapun prosedur penelitian ini adalah : (1)Tahap persiapan, meliputi :(a) Membuat surat persetujuan dosen pembimbing. (b) Menentukan masalah, judul, lokasi dan waktu penelitian. (c) Menyusun rancangan program pembelajaran (RPP). (d) Menyiapkan instrumen / tes pengumpul data. (2) Tahap pelaksanaan meliputi : (a) Menentukan sampel kelas eksperimen dan kelas kontrol dari populasi yang ada. (b) Melaksanakan pretes pada kedua kelas untuk mengetahui kemampuan awal siswa. (c) Melakukan analisis data pretes yaitu uji normalitas, dan uji homogenitas dan uji perbedaan nilai rata - rata pretes siswa pada kelas eksperimen dan kelas kontrol. (d) Memberikan perlakuan kepada kedua kelas. Pada kelas eksperimen diberi perlakuan dengan model pembelajaran kooperatif tipe NHT dan pada kelas kontrol diberi perlakuan dengan pembelajaran konvensional. (e) Memberikan postes kepada kedua kelas untuk mengetahui hasil belajar siswa terhadap materi yang telah di ajarkan. (3) Analisis data dan kesimpulan.
Uji normalitas dengan uji Lilliefors digunakan untuk mengetahui data kedua sampel beristribusi normal. Uji homogenitas digunakan untuk mengetahui apakah kedua sampel berasal dari populasi yang homogen. Uji hipotesis dengan uji $t$ digunakan untuk mengetahui adanya pengaruh dari suatu perlakuan.

\section{HASILDAN PEMBAHASAN}

Hasil pretes dan postes kelas eksperimen dan kontrol dapat dilihat pada Tabel 1.

Tabel 1. Data Nilai Pretes Kelas

Eksperimen dan Kelas Kontrol

\begin{tabular}{|c|c|c|c|c|c|c|}
\hline \multirow{2}{*}{ No } & \multicolumn{3}{|c|}{ Kelas Eksperimen } & \multicolumn{3}{|c|}{ Kelas Kontrol } \\
\hline & Nilai & F & Rerata & Nilai & F & Rerata \\
\hline 1 & 20 & 3 & \multirow{8}{*}{44,84} & 20 & 3 & \multirow{8}{*}{13,33} \\
\hline 2 & 26,7 & 6 & & 26,7 & 5 & \\
\hline 3 & 33,3 & 5 & & 33,3 & 3 & \\
\hline 4 & 40 & 2 & & 40 & 8 & \\
\hline 5 & 46,7 & 7 & & 46,7 & 8 & \\
\hline 6 & 53,3 & 7 & & 53,3 & 7 & \\
\hline 7 & 60 & 6 & & 60 & 2 & \\
\hline 8 & 66,7 & 4 & & 66,7 & 4 & \\
\hline & \multicolumn{2}{|l|}{$\Sigma=40$} & & \multicolumn{2}{|l|}{$\Sigma=40$} & \\
\hline
\end{tabular}

Secara lebih terperinci, data nilai pretes kedua kelas ditunjukkan pada Gambar 1.

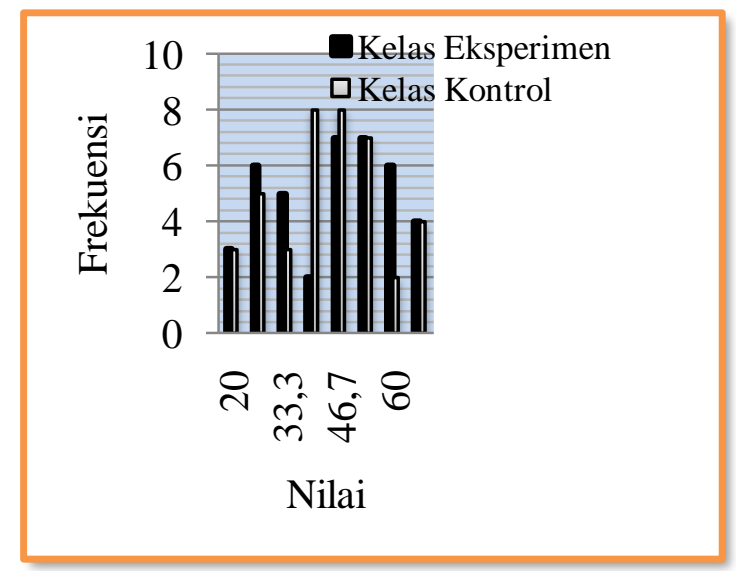

Gambar 1. Diagram batang data pretes kelas Eksperimen dan kelas Kontrol 
Tabel 2. Data Nilai Postes Kelas

Eksperimen dan Kelas Kontrol

\begin{tabular}{|c|c|c|c|c|c|c|}
\hline \multirow{2}{*}{ No } & \multicolumn{3}{|c|}{ Kelas Eksperimen } & \multicolumn{3}{|c|}{ Kelas Kontrol } \\
\hline & Nilai & $\mathbf{F}$ & Rerata & Nilai & $\mathbf{F}$ & Rerata \\
\hline 1 & 53,3 & 4 & \multirow{7}{*}{73,67} & 46,7 & 5 & \multirow{7}{*}{12,36} \\
\hline 2 & 60 & 4 & & 53,3 & 4 & \\
\hline 3 & 66,7 & 8 & & 60 & 7 & \\
\hline 4 & 73,3 & 7 & & 66,7 & 8 & \\
\hline 5 & 80 & 8 & & 73,3 & 6 & \\
\hline 6 & 86,7 & 5 & & 80 & 6 & \\
\hline 7 & 93,3 & 4 & & 86,7 & 4 & \\
\hline & $\Sigma=40$ & & & $\Sigma=40$ & & \\
\hline
\end{tabular}

Secara lebih terperinci, data nilai pretes kedua kelas dapat ditunjukkan dalam Gambar 1.

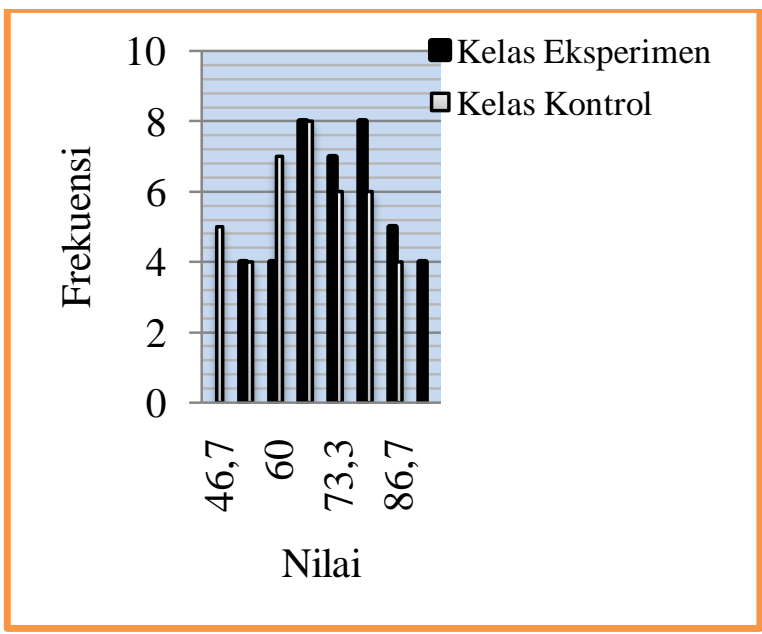

Gambar 2. Diagram batang data postes kelas Eksperimen dan kelas Kontrol

Pengujian normalitas data pretes pada kelas eksperimen dan kelas kontrol dilakukan dengan uji Lilliefors. Kriteria pengujian ini syaratnya apabila $\mathrm{L}_{\text {hitung }}<\mathrm{L}_{\text {tabel }}$ maka berdistribusi normal. Hasil yang diperoleh $\mathrm{L}_{\text {hitung }}<\mathrm{L}_{\text {tabel }}=0,1382$ $<0,1400$ maka data normal. Sementara untuk kelas kontrol $\mathrm{L}_{\text {hitung }}=0,098$ dan $\mathrm{L}_{\text {tabel }}=0,1400$ ( $\mathrm{L}_{\text {hitung }}<\mathrm{L}_{\text {tabel }}$ ) maka secara ringkas data pretes kelas eksperimen dan kelas kontrol disimpulkan berdistribusi normal seperti ditunjukkan pada Tabel 3.
Tabel 3. Uji Normalitas Data Kedua Kelompok Sampel

\begin{tabular}{|c|l|l|l|l|}
\hline No & \multicolumn{1}{|c|}{ Data } & Lhitung & \multicolumn{1}{|c|}{ Ltabel } & Kesimpulan \\
\hline 1. & $\begin{array}{l}\text { Pretes kelas } \\
\text { eksperimen }\end{array}$ & 0,1382 & 0,1400 & Normal \\
\hline 2. & $\begin{array}{l}\text { Pretes kelas } \\
\text { kontrol }\end{array}$ & 0,098 & 0,1400 & Normal \\
\hline
\end{tabular}

Data pretes kelas yang diperoleh setelah uji normalitas, kemudian dilakukan uji analisa data yang kedua yaitu uji homogenitas dengan uji $\mathrm{F}$ untuk mengetahui apakah kelompok sampel berasal dari populasi yang homogen atau tidak. Data dikatakan homogen memiliki kriteria jika $\mathrm{F}_{\text {hitung }}<\mathrm{F}_{\text {tabel. }}$ Berdasarkan hasil perhitungan yang diperoleh bahwa harga $F_{\text {hitung }}=1,21$ dan harga $F_{\text {tabel }}=1,75$ pada taraf signifikan $\alpha=0,05$. Sesuai dengan kriteria pengujian homogenitas syarat $\mathrm{F}_{\text {hitung }}<\mathrm{F}_{\text {tabel }}(1,21<1,75)$ maka data pretes kedua kelompok sampel berasal dari populasi yang homogen. Secara ringkas hasil perhitungan uji homogenitas data pretes kedua kelas ditunjukkan pada Tabel 4.

Tabel 4. Ringkasan Uji Homogenitas Varians Kedua Kelompok Sampel

\begin{tabular}{|l|l|l|l|l|l|}
\hline $\begin{array}{l}\text { N } \\
\mathbf{o}\end{array}$ & Data & Varians & F $_{\text {hitung }}$ & $\mathbf{F}_{\text {tabel }}$ & Kesimpulan \\
\hline 1. & $\begin{array}{l}\text { Pretes } \\
\text { kelas } \\
\text { eksperi } \\
\text { men }\end{array}$ & 214,19 & 1,21 & 1,75 & Homogen \\
\hline 2. & $\begin{array}{l}\text { Pretes } \\
\text { kelas } \\
\text { kontrol }\end{array}$ & 177,65 & & \\
\hline
\end{tabular}

$$
\text { Pengujian }
$$

Hipotesis

Kemampuan Pretes. Hasil pemberian pretes kepada kelas eksperimen dan kelas kontrol diperoleh nilai ratarata untuk kelas eksperimen adalah 44,84 dan nilai rata-rata kelas kontrol adalah 43,67. Ringkasan 
perhitugan uji hipotesis untuk kemampuan pretes kelas eksperimen dan kelas kontrol ditunjukkan pada Tabel 5.

Tabel 5. Ringkasan Perhitungan Uji Hipotesis Kemampuan Pretes

\begin{tabular}{|c|c|c|c|c|c|}
\hline $\begin{array}{c}\mathbf{N} \\
\mathbf{o}\end{array}$ & $\begin{array}{c}\text { Data } \\
\text { Kelas }\end{array}$ & $\begin{array}{c}\text { Nilai } \\
\text { Rerata }\end{array}$ & t $_{\text {hit }}$ & $\mathbf{t}_{\mathrm{taB}}$ & Kesimpulan \\
\hline 1 & $\begin{array}{l}\text { Eksperi } \\
\text { men }\end{array}$ & 44,84 & \multirow{2}{*}{0,380} & 1,99 & Ho diterima \\
\hline 2 & Kontrol & 443,67 & & \\
\hline
\end{tabular}

Berdasarkan Tabel 5 perhitungan uji perbedaan nilai ratarata pretes kelas eksperimen dan kelas kontrol untuk $\alpha=0,05$ dapat disimpulkan bahwa kemampuan awal siswa pada kelas eksperimen sama dengan kemampuan awal siswa pada kelas kontrol $t_{\text {hitung }}<t_{\text {tabel }}$ yaitu $0,380<1,99$. Sehingga $\mathrm{H}_{\mathrm{a}}$ diterima.

Setelah siswa di kelas eksperimen diberikan perlakuan, maka hasil pemberian postest pada kelas eksperimen dan kelas kontrol diperoleh nilai rata-rata hasil belajar untuk kelas eksperimen adalah 73,67 sedangkan untuk kelas kontrol adalah 66,67. Ringkasan perhitugan uji hipotesis untuk kemampuan postest kelas eksperimen dan kelas kontrol di tunjukkan pada Tabel 6 .

Tabel 6. Ringkasan Perhitungan Uji Hipotesis Kemampuan Postes

\begin{tabular}{|c|c|c|c|c|c|}
\hline No & $\begin{array}{c}\text { Data } \\
\text { Kelas }\end{array}$ & $\begin{array}{c}\text { Nilai } \\
\text { Rata- } \\
\text { rata }\end{array}$ & thit & $t_{\text {tab }}$ & Kesimpulan \\
\cline { 1 - 3 } 1 & $\begin{array}{c}\text { Eksperim } \\
\text { en }\end{array}$ & 73,67 & 2,63 & 1,67 & Ha diterima \\
\hline 2 & Kontrol & 66,67 & \\
\hline
\end{tabular}

Berdasarkan Tabel 6, dapat diperoleh $t_{\text {hitung }}>t_{\text {tabel }}(2,63>1,67)$, sehingga dapat disimpulkan bahwa ada pengaruh model pembelajaran kooperatif tipe Numbered Head
Together (NHT) terhadap hasil belajar siswa pada Materi Usaha dan Energi di kelas XI Semester I SMA Negeri 1 Percut Sei T.P 2013/2014.

\section{KESIMPULAN}

Berdasarkan hasil analisis data dapat disimpulkan bahwa adanya peningkatan hasil belajar siswa yang signifikan jika diberi penerapan model pembelajaran kooperatif tipe Numbered Head Together (NHT) dibandingkan dengan pembelajaran konvensional pada materi Usaha dan Energi.

Adapun saran dalam menerapkan model pembelajaran kooperatif tipe Numbered Head Together (NHT) adalah : (1) Kepada peneliti selanjutnya yang ingin meneliti tentang model pembelajaran kooperatif Numbered Head Together (NHT) pada materi yang lain, ada baikmya memberikan motivasi terlebih dahulu kepada siswa yang akan mempresentasikan hasil diskusi untuk meningkatkan rasa percaya diri pada siswa tersebut karena dengan kooperatif tipe Numbered Head Together (NHT) tidak semuanya siswa siap untuk mempresentasikan hasil diskusi ketika nomor anggotanya dipanggil oleh guru. (2) Kepada peneliti selanjutnya di harapkan lebih memperhatikan penggunaan waktu di dalam pembelajaran untuk setiap fase dalam Numbered Head Together (NHT) karena pada kooperatif tipe Numbered Head Together (NHT) memerlukan waktu yang banyak khususnya ketika mempresentasikan hasil diskusi. 


\section{DAFTAR PUSTAKA}

Arends, R.I., ( 2008)., Learning To Teach Belajar Untuk Mengajar. Cetakan Pertama. Pustaka Pelajar,Yogyakarta.

Arikunto, S., (2009), Dasar - Dasar Evaluasi pendidikan., Penerbit Bumi Aksara., Jakarta.

Isjoni, (2009), Cooperative Learning, Alfabeta, Bandung.
Lie, A., (2010), Cooperative Learning, Mempraktikkan Cooperative Learning Di Ruang-ruang Kelas. Penerbit PT Gramedia Widiasarana Indonesia., Jakarta.

Sudjana, (2005), Metoda Statistika, PT Tarsito, Bandung

Sudrajat,A.,(2008).,http://akhmadsud rajat.wordpress.com/2008/11/08/ hakikat pendidikan (diakses 5 maret 2013) 